\title{
RADIOCARBON DATING OF ANODONTA IN THE MOJAVE RIVER BASIN
}

\section{RAINER BERGER}

Institute of Geophysics and Planetary Physics, and Department of Geography, University of California, Los Angeles, California 90024 USA

and

\section{NORMAN MEEK}

Department of Geography, California State University, San Bernardino, California 92407 USA

\begin{abstract}
A 450-year correction is required to make Anodonta ${ }^{14} \mathrm{C}$ dates comparable to ${ }^{14} \mathrm{C}$ dates on other materials in the Mojave River basin. The internal stratigraphic consistency of 34 conventional ${ }^{14} \mathrm{C}$ dates on Anodonta in this drainage basin indicates that such dates are usually reliable. The validity of most conventional ${ }^{14} \mathrm{C}$ dates in the Mojave River basin may be a product of the basin's crystalline bedrock in a region usually typified by thick Paleozoic carbonate sections.
\end{abstract}

\section{INTRODUCTION AND BACKGROUND}

This paper presents the results of extensive radiocarbon dating, and the establishment of a correction term, for a freshwater pelecypod, Anodonta californiensis, in the Mojave River drainage basin of inland southern California (Fig. 1). During the late Pleistocene, Anodonta thrived in the pluvial lakes of the southwestern U.S., and extensive deposits of Anodonta shells have been found embedded in shoreline features and other lacustrine deposits throughout this region. Radiocarbon dating of these shells and associated sedimentary deposits has permitted paleoclimatologists to reconstruct some ancient lake-level fluctuations, and thus derive a proxy record of Pleistocene climatic shifts in the Mojave Desert (Ore \& Warren 1971; Wells et al. 1989; Meek 1990).

Today, Anodonta are abundant in rivers of the northwestern U.S., and some remnant populations can be found locally in the southwestern U.S. (Ingram 1948). Anodonta prefer slightly alkaline waters with gentle currents, and live and burrow in sand or gravel flats at water depths of less than $2 \mathrm{~m}$. They avoid locations with rooted vegetation. Most late Pleistocene Anodonta shells have been recovered from sites that experienced rapid burial, such as where a delta prograded into a basin during a flood, or in overwash deposits on beach ridges. Thus, fossil Anodonta sites often indicate approximate water levels at times of infrequent but rapid depositional events.

In this study, Anodonta shells were recovered from shoreline features of Lake Manix, a pluvial lake in the central Mojave Desert, that was the effective terminus of the Mojave River during most of the late Quaternary. Based on extensive paleontological and paleoecological evidence (Jefferson 1985, 1987; Steinmetz 1988), it appears that Pleistocene Lake Manix was much like the modern, shallow, marshy lakes in the rainshadow of the Cascades in northern California, Oregon and Washington. The complex Wisconsinan climate history generated by the new shell dates is beyond the scope of this paper, but has been reported by Meek (1990, and forthcoming).

Prior to this study, 14 finite ${ }^{14} \mathrm{C}$ age estimates had been published on materials associated with Lake Manix or post-lacustrine deposits in the Manix basin (Table 1). We collected 13 new ${ }^{14} \mathrm{C}$ samples, consisting of lustrous Anodonta californiensis shells and tufa from a variety of locations in the Manix basin (Table 2). Each sample was freed from external contamination by mechanical cleaning and subsequent washing in distilled water. Samples were then dissolved in dilute cold hydrochloric acid. The outer shell layer was removed by discarding the initial $\mathrm{CO}_{2}$ fraction. The 


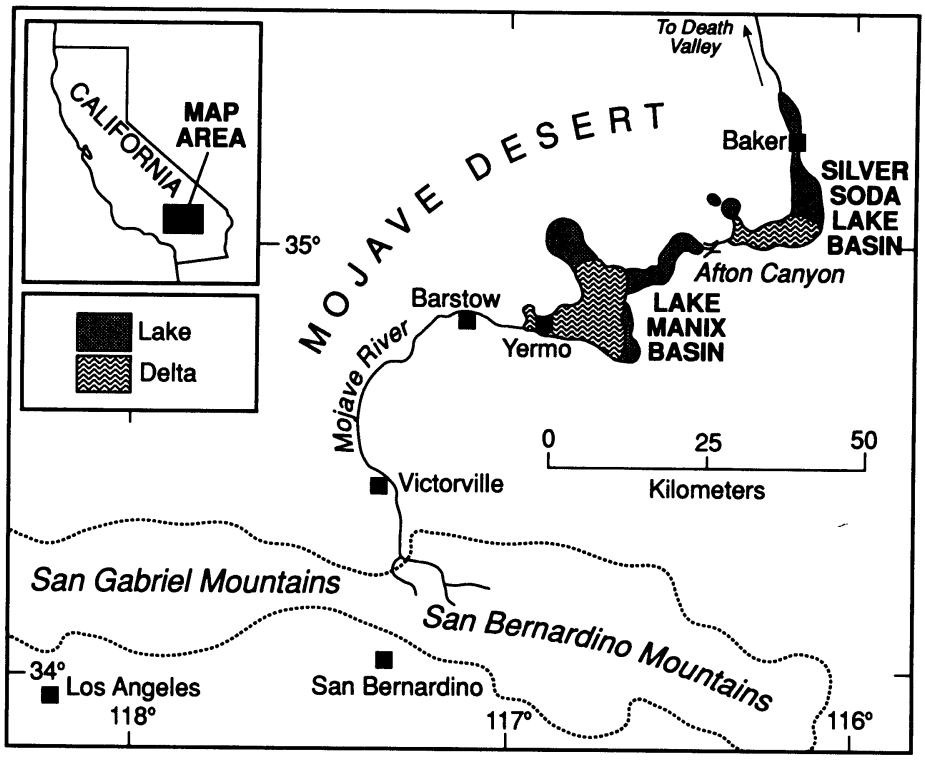

Fig. 1. Map of the Mojave River basin, California

TABLE 1. Published ${ }^{14} \mathrm{C}$ Dates (Uncorrected) From the Manix Basin

\begin{tabular}{lllll}
\hline $\begin{array}{l}\text { ID } \\
\text { code }\end{array}$ & ${ }^{14}$ C age $(\mathrm{yr} \mathrm{BP})$ & $\begin{array}{l}\text { Sample } \\
\text { material }\end{array}$ & Lab no. & Reference \\
\hline d1 & $30,950 \pm 1000$ & Tufa & LJ-895 & Hubbs, Bien \& Suess (1965) \\
d2 & $20,050 \pm ?$ & Anodonta & $*$ & Bassett \& Jefferson (1971) \\
d3 & $19,500 \pm 500$ & Tufa & LJ-269 & Hubbs, Bien \& Suess (1962) \\
d4 & $19,300 \pm 400$ & Tufa & UCLA-121 & Fergusson \& Libby (1962) \\
d5 & $19,100 \pm 250$ & Anodonta & QC-1467 & Jefferson (1985) \\
d6 & $16,750 \pm 1000^{* *}$ & Tufa & UCLA-1079 & Berger \& Libby (1967) \\
d7 & $13,800 \pm 600$ & Anodonta & LJ-958 & Hubbs, Bien \& Suess (1965) \\
d8 & $12,800 \pm 900$ & Bone & GX-10417 & Reynolds \& Reynolds (1985) \\
d9 & $12,210 \pm 430$ & Charcoal & GX-10420 & Reynolds \& Reynolds (1985) \\
d10 & $10,910 \pm 425$ & Charcoal & GX-10421 & Reynolds \& Reynolds (1985) \\
d11 & $9050 \pm 350$ & Charcoal & GX-10418 & Reynolds \& Reynolds (1985) \\
d12 & $7350 \pm 115$ & Charcoal & QC-937 & Reynolds \& Reynolds (1985) \\
d13 & $2090 \pm 105$ & Charcoal & QC-939A & Reynolds \& Reynolds (1985) \\
d14 & $1570 \pm 170$ & Charcoal & GX-10419 & Reynolds \& Reynolds (1985) \\
\hline
\end{tabular}

*Not available

**Artificial 2500-yr correction term removed

remaining bulk $\mathrm{CO}_{2}$ was collected and extensively purified by washing in silver nitrate solution and chromic acid. After drying, the gas was treated with hot copper for removal of traces of electronegative impurities. All samples were then stored for at least one month to allow for radon decay. Thereafter, each sample was assayed in a proportional counter for at least $3000 \mathrm{~min}$ for good statistical precision. Table 2 presents these new ${ }^{14} \mathrm{C}$ dates. 
TABLE 2. New ${ }^{14} \mathrm{C}$ Dates (Uncorrected) From the Manix Basin

\begin{tabular}{llllll}
\hline ID & ${ }^{14}$ C age & Sample & & \multicolumn{2}{c}{ UTM location (Zone 11) } \\
code & $(\mathrm{yr}$ BP $)$ & material & Lab no. & Easting & Northing \\
\hline $\mathrm{d} 15$ & $30,650 \pm 890$ & Anodonta & UCLA-2604 & 557500 & 3878300 \\
$\mathrm{~d} 16$ & $23,090 \pm 445$ & Anodonta & UCLA-2600A & 558800 & 3877300 \\
$\mathrm{~d} 17$ & $20,890 \pm 345$ & Tufa & UCLA-2602 & 538350 & 3866450 \\
$\mathrm{~d} 18$ & $19,700 \pm 260$ & Tufa & UCLA-2600B & 558800 & 3877300 \\
$\mathrm{~d} 19$ & $18,150 \pm 400$ & Anodonta & UCLA-2607 & 555950 & 3875900 \\
$\mathrm{~d} 20$ & $17,590 \pm 1500$ & Anodonta & UCLA-2603 & 527600 & 3877400 \\
$\mathrm{~d} 21$ & $15,125 \pm 270$ & Anodonta & UCLA-2608 & 528200 & 3879500 \\
$\mathrm{~d} 22$ & $15,025 \pm 230$ & Anodonta & UCLA-2605 & 540550 & 3856200 \\
$\mathrm{~d} 23$ & $14,230 \pm 1325$ & Anodonta & UCLA-2601 & 557650 & 3878300 \\
$\mathrm{~d} 24$ & $13,560 \pm 145$ & Anodonta & UCLA-2609B & 528700 & 3878600 \\
$\mathrm{~d} 25$ & $12,900 \pm 120$ & Anodonta & UCLA-2606 & 522600 & 3874300 \\
$\mathrm{~d} 26$ & $11,810 \pm 100$ & Anodonta & UCLA-2609C & 528600 & 3878800 \\
$\mathrm{~d} 27$ & $480 \pm 60$ & Anodonta & UCLA-2610A & \multicolumn{2}{c}{ (see text) } \\
\hline
\end{tabular}

\section{DISCUSSION}

Initial research on the reliability of ${ }^{14} \mathrm{C}$ age estimates on Anodonta in the Mojave Desert led Hubbs, Bien and Suess (1965: 69) to conclude that Anodonta provide reasonably reliable age estimates when solid, lustrous shells are dated. Consequently, in the literature, no previous ${ }^{14} \mathrm{C}$ dates on Anodonta have been corrected for variable ${ }^{14} \mathrm{C}$ uptake by the genus.

Without knowledge of the ${ }^{14} \mathrm{C}$ uptake of Anodonta, the chronologies of lake basins in the Great Basin, which depend heavily on shell dates, are not directly comparable to ${ }^{14} \mathrm{C}$ chronologies based on charcoal, e.g., which have been thoroughly studied. For this reason, we conducted a study on the ${ }^{14} \mathrm{C}$ uptake of Anodonta in southern California.

Local malacologists believe that Anodonta may have become extinct in the lower Mojave River drainage basin earlier this century because of human disturbances. Thus, it was not possible to obtain modern specimens from this drainage basin. However, before atmospheric atomic-bomb testing began in the 1940s, Anodonta californiensis shells were collected from the Mojave River drainage and in ponds in the Los Angeles basin. These shells were obtained through the courtesy of Dr. Clifton Coney, malacology collection manager at the Los Angeles County Museum of Natural History.

The inorganic fraction of a mixture of two Anodonta californiensis samples was ${ }^{14} \mathrm{C}$ dated. One sample of two specimens (4 valves; $25.8 \mathrm{~g}$ ) was collected on 18 October 1934 in a Mojave River pool about $10 \mathrm{~km}$ east of Yermo, California, by W. Branaler. The other sample consisted of one specimen ( 2 valves; $9.5 \mathrm{~g}$ ), collected in 1915 by E. P. Chase in East Lake Park, Los Angeles County. All of the specimens were adults, probably about 10 years old at the time of collection. Because these samples were collected prior to the discovery of ${ }^{14} \mathrm{C}$ dating, no data exist on the ${ }^{14} \mathrm{C}$ content of the water in which they were found. In the 50+ years since the shells were collected, the pools in the Mojave River have been highly disturbed by cattle ranching and offroad vehicles, and the ponds in the Los Angeles basin have experienced similar radical changes. Thus, we assume that the ${ }^{14} \mathrm{C}$ content of the water from which the samples were collected earlier this century was similar to the shallow, and probably well-mixed, water of Lake Manix. 
${ }^{14} \mathrm{C}$ dating of the inorganic fraction of these shells provided an age of $480 \pm 60 \mathrm{BP}$ on specimens with a true age of $\mathrm{ca} .30{ }^{14} \mathrm{C}$ years. Thus, this study suggests that age estimates on Anodonta californiensis in the Mojave River basin require an approximate 450-year correction term.

This correction term is substantially less than the approximate $1870 \pm 240$-year correction term required for specimens of Anodonta californiensis living in the Humboldt River at Dunphy, Nevada (Broecker \& Olson 1959). The difference is probably attributable to large geochemical differences between the Mojave River and the Humboldt River basins. Unlike the Mojave River, the Humboldt River flows through a region of thick Paleozoic carbonates, which probably contribute significant amounts of dead carbon to the stream.

On the other hand, in the Cronese basin, which is just downstream from the Lake Manix basin, only a 350-year difference may exist between Anodonta and charcoal. Joan Schneider (written communication, 1989) reports an age of $910 \pm 100$ on Anodonta shells (UCR-2385) found in the upper playa clays, whereas charcoal in a nearby location provided an age of $560 \pm 110 \mathrm{BP}$ (UCR767; Drover 1979). It is important to note that these two samples were not collected adjacent to each other, and so their age relationship is not firmly established.

Table 3 presents corrected Anodonta ${ }^{14} \mathrm{C}$ dates using the 450-year correction term for comparison with charcoal dates from the region. ${ }^{13} \mathrm{C}$ measurements were also completed, but only if ${ }^{13} \mathrm{C}$ corrections exceed the ${ }^{14} \mathrm{C}$ statistical error ranges have the error ranges been increased to accommodate the $\delta^{13} \mathrm{C}$ variations.

TABLE 3. Corrected ${ }^{14} \mathrm{C}$ Dates From the Manix Basin

\begin{tabular}{lcclcl}
\hline ID & $\begin{array}{c}\delta^{13} \mathrm{C} \\
\text { code }\end{array}$ & $\begin{array}{l}\text { Corr. } \\
(\mathrm{yr})\end{array}$ & $\begin{array}{l}\text { Sample } \\
\text { material }\end{array}$ & $\begin{array}{c}\text { Corrected }{ }^{14} \mathrm{C} \text { age } \\
(\mathrm{yr} \mathrm{BP})\end{array}$ & Lab no. \\
\hline $\mathrm{d} 1$ & $*$ & $*$ & Tufa & $30,950 \pm 1000$ & LJ-895 \\
$\mathrm{cd} 2$ & $*$ & $*$ & Anodonta & $19,600 \pm ?$ & $*$ \\
$\mathrm{~d} 3$ & $*$ & $*$ & Tufa & $19,500 \pm 500$ & LJ-269 \\
$\mathrm{d} 4$ & $*$ & $*$ & Tufa & $19,300 \pm 400$ & UCLA-121 \\
$\mathrm{cd} 5$ & $*$ & $*$ & Anodonta & $18,650 \pm 250$ & QC-1467 \\
$\mathrm{d} 6$ & $*$ & $*$ & Tufa & $16,750 \pm 1000$ & UCLA-1079 \\
$\mathrm{cd} 7$ & $*$ & $*$ & Anodonta & $13,350 \pm 600$ & LJ-958 \\
$\mathrm{cd} 15$ & -19.39 & 90 & Anodonta & $30,200 \pm 890$ & UCLA-2604 \\
$\mathrm{cd} 16$ & $*$ & $*$ & Anodonta & $22,640 \pm 445$ & UCLA-2600A \\
$\mathrm{cd} 17$ & +0.60 & 410 & Tufa & $20,890 \pm 410$ & UCLA-2602 \\
$\mathrm{cd} 18$ & +1.29 & 420 & Tufa & $19,700 \pm 420$ & UCLA-2600B \\
$\mathrm{cd} 19$ & -8.03 & 270 & Anodonta & $17,700 \pm 400$ & UCLA-2607 \\
$\mathrm{cd} 20$ & $*$ & $*$ & Anodonta & $17,140 \pm 1500$ & UCLA-2603 \\
$\mathrm{cd} 21$ & -1.54 & 375 & Anodonta & $14,675 \pm 375$ & UCLA-2608 \\
$\mathrm{cd} 22$ & -8.76 & 260 & Anodonta & $14,575 \pm 260$ & UCLA-2605 \\
$\mathrm{cd} 23$ & $*$ & $*$ & Anodonta & $13,780 \pm 1325$ & UCLA-2601 \\
$\mathrm{cd} 24$ & -6.96 & 290 & Anodonta & $13,110 \pm 290$ & UCLA-2609B \\
$\mathrm{cd} 25$ & -4.53 & 330 & Anodonta & $12,450 \pm 330$ & UCLA-2606 \\
$\mathrm{cd} 26$ & -3.56 & 340 & Anodonta & $11,360 \pm 340$ & UCLA-2609C \\
$\mathrm{cd} 27$ & -16.21 & 140 & Calib. & $480 \pm 140$ & UCLA-2610A \\
\hline
\end{tabular}

*Not available 
Two new ${ }^{14} \mathrm{C}$ dates (Table 2) were also measured on lithoid tufa in deposits where both Anodonta and tufa are found in the same outcrop. The Manix basin results, supplemented with the Silver/Soda Lake basin results, suggest that lithoid tufa usually provides reliable age estimates in the Mojave River drainage basin when compared with the corrected Anodonta dates. This is not surprising because of the relative absence of carbonate bedrock in the drainage basin, and the fact that the primary water source was in the San Bernardino Mountains, which are composed predominately of crystalline rocks.

Table 4 presents a sequential summary of all known finite conventional ${ }^{14} \mathrm{C}$ dates from the Manix basin and downstream areas. Because Anodonta correction terms were used in this study, the Manix basin dates were not directly comparable to unadjusted ${ }^{14} \mathrm{C}$ dates in downstream areas. We have corrected the Anodonta dates from a list of Silver/Soda Lake basin ${ }^{14} \mathrm{C}$ dates compiled by Wells et al. (1989). Only conventional ${ }^{14} \mathrm{C}$ dates on shells and tufa are reported in Table 4, although six additional AMS dates on the organic fraction of bulk sediments from cores have been reported in the Silver/Soda Lake basin.

One unusual aspect of the Manix basin is that it broke in what may have been a catastrophic flood about 13,800 BP, carving Afton Canyon and allowing the Mojave River to flow directly downstream into the Silver/Soda Lake basin (Meek 1989, 1990).

When combined, the conventional ${ }^{14} \mathrm{C}$ dates from the Manix basin correspond exceedingly well with ${ }^{14} \mathrm{C}$ dates from the Silver/Soda Lake basin. Of all the conventional ${ }^{14} \mathrm{C}$ dates yet published, only three dates from the Silver/Soda Lake basin overlap with dates on lacustrine features from Lake Manix, and the maximum overlap is $2040{ }^{14} \mathrm{C}$ years. Some overlap is to be expected, because during the late Wisconsinan glaciation, Anodonta should have been living in lakes downstream from Lake Manix before it drained. In other words, of the 57 conventional ${ }^{14} \mathrm{C}$ dates derived from the 2 basins, only 3 indicate that a lake existed downstream before Lake Manix broke, and no ${ }^{14} \mathrm{C}$

TABLE 4. Sequential Summary of Conventional ${ }^{14} \mathrm{C}$ Dates From the Mojave River Drainage Basin

\begin{tabular}{ccclll}
\hline $\begin{array}{c}\text { Manix } \\
\text { Basin }\end{array}$ & $\begin{array}{c}\text { Silver } \\
\text { Basin }\end{array}$ & $\begin{array}{c}\text { ID code } \\
(\text { Meek 1990) }\end{array}$ & $\begin{array}{c}\text { Corr. }{ }^{14} \mathrm{C} \text { age } \\
(\mathrm{yr} \mathrm{BP})\end{array}$ & $\begin{array}{c}\text { Sample } \\
\text { type }\end{array}$ & \multicolumn{1}{c}{ Lab no. } \\
\hline $\mathrm{X}$ & & $\mathrm{d} 1$ & $30,950 \pm 1000$ & Tufa & LJ-895 \\
$\mathrm{X}$ & & $\mathrm{cd} 15$ & $30,200 \pm 890$ & Anodonta & UCLA-2604 \\
$\mathrm{X}$ & & $\mathrm{cd} 16$ & $22,640 \pm 445$ & Anodonta & UCLA-2600A \\
$\mathrm{X}$ & & $\mathrm{cd} 17$ & $20,890 \pm 410$ & Tufa & UCLA-2602 \\
$\mathrm{X}$ & & $\mathrm{cd} 18$ & $19,700 \pm 420$ & Tufa & UCLA-2600B \\
$\mathrm{X}$ & & $\mathrm{cd} 2$ & $19,600 \pm ?$ & Anodonta & $*$ \\
$\mathrm{X}$ & & $\mathrm{d} 3$ & $19,500 \pm 500$ & Tufa & LJ-269 \\
$\mathrm{X}$ & & $\mathrm{d} 4$ & $19,300 \pm 400$ & Tufa & UCLA-121 \\
$\mathrm{X}$ & & $\mathrm{cd} 5$ & $18,650 \pm 250$ & Anodonta & QC-1467 \\
$\mathrm{X}$ & & $\mathrm{cd} 19$ & $17,700 \pm 400$ & Anodonta & UCLA-2607 \\
$\mathrm{X}$ & & $\mathrm{cd} 20$ & $17,140 \pm 1500$ & Anodonta & UCLA-2603 \\
$\mathrm{X}$ & & $\mathrm{d} 6$ & $16,750 \pm 1000$ & Tufa & UCLA-1079 \\
& $\mathrm{X}$ & $\mathrm{s} 1$ & $15,820 \pm 310$ & Anodonta & Beta-29553 \\
& $\mathrm{X}$ & $\mathrm{s} 2$ & $14,900 \pm 240$ & Anodonta & Y-1587 \\
$\mathrm{X}$ & & $\mathrm{cd} 21$ & $14,675 \pm 375$ & Anodonta & UCLA-2608 \\
$\mathrm{X}$ & & $\mathrm{cd} 22$ & $14,575 \pm 260$ & Anodonta & UCLA-2605 \\
$\mathrm{X}$ & $\mathrm{X}$ & $\mathrm{s} 3$ & $14,100 \pm 140$ & Anodonta & Y-1586 \\
& & $\mathrm{cd} 23$ & $13,780 \pm 1325$ & Anodonta & UCLA-2601
\end{tabular}


TABLE 4. (Continued)

\begin{tabular}{lccccc}
\hline Manix & Silver & ID code & Corr. ${ }^{14} \mathrm{C}$ age & Sample & \\
Basin & Basin & (Meek 1990) & (yr BP) & type & Lab no. \\
\hline
\end{tabular}

Afton Basin Permanently Drained - (all of the following Manix basin ${ }^{14} \mathrm{C}$ dates are from sites that postdate the high stand of Lake Manix, and are related to Mojave River delta migration)

\begin{tabular}{|c|c|c|c|c|c|}
\hline $\mathrm{X}$ & & $\mathrm{cd} 7$ & $13,350 \pm 600$ & Anodonta & LJ-958 \\
\hline & $\mathrm{X}$ & s4 & $13,220 \pm 550$ & Anodonta & LJ-933 \\
\hline & $\mathrm{X}$ & s5 & $13,190 \pm 500$ & Tufa & LJ-931 \\
\hline & $\mathrm{X}$ & s6 & $13,190 \pm 120$ & Anodonta & Beta-26456 \\
\hline & $\mathrm{X}$ & s7 & $13,170 \pm 160$ & Anodonta & Y-1585** \\
\hline $\mathrm{X}$ & & $\operatorname{cd} 24$ & $13,110 \pm 290$ & Anodonta & UCLA-2609B \\
\hline & $\mathrm{X}$ & s8 & $13,040 \pm 120$ & Tufa & Y-1588 \\
\hline & $\mathrm{X}$ & s9 & $12,840 \pm 550$ & Anodonta & Y-1589 \\
\hline $\mathrm{X}$ & & $\mathrm{d} 8$ & $12,800 \pm 900$ & Bone & GX-10417 \\
\hline & $\mathrm{X}$ & s10 & $12,700 \pm 350$ & Anodonta & I -443 \\
\hline $\mathrm{X}$ & & $\operatorname{cd} 25$ & $12,450 \pm 330$ & Anodonta & UCLA-2606 \\
\hline $\mathrm{X}$ & & d9 & $12,210 \pm 430$ & Charcoal & GX-10420 \\
\hline & $\mathrm{X}$ & s11 & $12,000 \pm 160$ & Anodonta & Y-2408 \\
\hline & $\mathrm{X}$ & s12 & $11,630 \pm 500$ & Tufa & LJ-934 \\
\hline & $\mathrm{X}$ & s13 & $11,570 \pm 130$ & Anodonta & Beta-21299 \\
\hline & $\mathrm{X}$ & s14 & $11,520 \pm 160$ & Anodonta & $*$ \\
\hline & $\mathrm{X}$ & s15 & $11,410 \pm 95$ & Anodonta & DIC-2824 \\
\hline $\mathrm{X}$ & & $\operatorname{cd} 26$ & $11,360 \pm 340$ & Anodonta & UCLA-2609C \\
\hline & $\mathrm{X}$ & s16 & $11,320 \pm 120$ & Tufa & Y-1590 \\
\hline $\mathrm{X}$ & & $\mathrm{d} 10$ & $10,910 \pm 425$ & Charcoal & GX-10421 \\
\hline & $\mathrm{X}$ & s17 & $10,870 \pm 450$ & Tufa & LJ-930 \\
\hline & $\mathrm{X}$ & s18 & $10,850 \pm 75$ & Tufa & DIC-2823 \\
\hline & $\mathrm{X}$ & s19 & $10,250 \pm 100$ & Anodonta & Y-1591 \\
\hline & $\mathrm{X}$ & s20 & $10,130 \pm 100$ & Anodonta & Y-1593 \\
\hline & $\mathrm{X}$ & s21 & $9990 \pm 100$ & Tufa & Y-1592 \\
\hline & $\mathrm{X}$ & s22 & $9960 \pm 200$ & Tufa & $Y-2410$ \\
\hline & $\mathrm{X}$ & s23 & $9880 \pm 120$ & Anodonta & Beta-21200 \\
\hline & $\mathrm{X}$ & s24 & $9820 \pm 160$ & Anodonta & Y-2406 \\
\hline & $\mathrm{X}$ & s25 & $9810 \pm 400$ & Anodonta & LJ-932 \\
\hline & $\mathrm{X}$ & s26 & $9550 \pm 300$ & Anodonta & $\mathrm{I}-444$ \\
\hline & $\mathrm{X}$ & s27 & $9190 \pm 240$ & Anodonta & LJ-200 \\
\hline & $\mathrm{X}$ & s28 & $9160 \pm 400$ & Tufa & LJ-935 \\
\hline $\mathrm{X}$ & & d11 & $9050 \pm 350$ & Charcoal & GX-10418 \\
\hline & $\mathrm{X}$ & s29 & $8940 \pm 140$ & Anodonta & Beta-29552 \\
\hline & $\mathrm{X}$ & s30 & $8890 \pm 140$ & Anodonta & Y-2407 \\
\hline & $\mathrm{X}$ & s31 & $8350 \pm 300$ & Tufa & LJ-929 \\
\hline $\mathrm{X}$ & & $\mathrm{d} 12$ & $7350 \pm 115$ & Charcoal & QC-937 \\
\hline $\mathrm{X}$ & & $\mathrm{d} 13$ & $2090 \pm 105$ & Charcoal & QC-939A \\
\hline $\mathrm{X}$ & & d14 & $1570 \pm 170$ & Charcoal & GX-10419 \\
\hline
\end{tabular}

*Not available

**The error range of this date has been consistently misreported as $\pm 100 \mathrm{yr}$ since the Ore and Warren (1971) publication; see Stuiver (1969). 
dates exist on lacustrine materials in the part of Manix basin that was permanently drained after Afton Canyon had formed. We believe that this is a testament to the reliability of conventional ${ }^{14} \mathrm{C}$ dates on Anodonta in the Mojave River basin.

\section{CONCLUSIONS}

We believe that a genus-specific correction term of 450 years is required to make Anodonta ${ }^{14} \mathrm{C}$ dates in the Mojave River drainage basin comparable to ${ }^{14} \mathrm{C}$ dates on other materials.

Because of the relative absence of carbonate bedrock in the Mojave River drainage basin, conventional ${ }^{14} \mathrm{C}$ dates on Anodonta, as well as lithoid tufa dates, are usually reliable. This conclusion is based on the regional stratigraphic consistency of more than 50 conventional ${ }^{14} \mathrm{C}$ dates. Knowledge of the apparent reliability of conventional ${ }^{14} \mathrm{C}$ dates on Anodonta in the Mojave River drainage basin will greatly enhance future geomorphic and paleoclimatic studies of this important region.

\section{ACKNOWLEDGMENTS}

We thank Dr. Clifton Coney, Los Angeles County Museum of Natural History, for help in obtaining pre-atomic-bomb Anodonta specimens. This research was funded by a NSF Dissertation Improvement Grant \#SES-8719442.

\section{REFERENCES}

Bassett, A. M. and Jefferson, G. T. 1971 Radiocarbon dates of Manix Lake, central Mojave Desert, California. Abstract. Geological Society of America, $A b$ stracts with Programs 3: 79-80.

Berger, R. and Libby, W. F. 1967 UCLA radiocarbon dates VI. Radiocarbon 9: 477-504.

Broecker, W. S. and Olson, E. A. 1959 Lamont radiocarbon measurements VI. American Journal of Science Radiocarbon Supplement 1: 111-132.

Drover, C. E. (ms.) 1979 The late prehistoric human ecology of the northern Mohave Sink, San Bernardino County, California. Ph.D. dissertation, University of California, Riverside: 255 p.

Fergusson, G. J. and Libby, W. F. 1962 UCLA radiocarbon dates I. Radiocarbon 4: 109-114.

Hubbs, C. L., Bien, G. S. and Suess, H. E. 1962 La Jolla natural radiocarbon measurements II. Radiocarbon 4: 204-238.

$1965 \mathrm{La}$ Jolla natural radiocarbon measurements IV. Radiocarbon 7: 66-117.

Ingram, W. M. 1948 The larger freshwater clams of California, Oregon and Washington. Journal of Entomology and Zoology 40(4): 72-92.

Jefferson, G. T. 1985 Stratigraphy and geologic history of the Pleistocene Manix Formation, central Mojave Desert, California. In Reynolds, R. E., compiler, Geologic Investigations Along Interstate 15, Cajon Pass to Manix Lake, California. San Bernardino County Museum Special Publication, Redlands: 157-169.

1987 The Camp Cady local fauna, paleoenvironment of the Lake Manix basin. San Bernardino County Museum Association Quarterly 34(3-4): 3-35.
Meek, N. 1989 Geomorphic and hydrologic implications of the rapid incision of Afton Canyon, Mojave Desert, California. Geology 17: 7-10.

(ms.) 1990 Late Quaternary geochronology and geomorphology of the Manix basin, San Bernardino County, California. Ph.D. dissertation, University of California, Los Angeles: $212 \mathrm{p}$.

Ore, H. T. and Warren, C. N. 1971 Late Pleistoceneearly Holocene geomorphic history of Lake Mojave, California. Geological Society of America Bulletin 82: 2553-2562.

Reynolds, R. E. and Reynolds, R. L. 1985 Late Pleistocene faunas from Daggett and Yermo, San Bernardino County, California. In Reynolds, R. E., compiler, Geologic investigations Along Interstate 15, Cajon Pass to Manix Lake, California. San Bernardino County Museum Special Publication, Redlands: 175-191.

Steinmetz, J. J. (ms.) 1988 Biostratigraphy and paleoecology of limnic ostracodes from the late Pleistocene Manix Formation. M.S. thesis, California State Polytechnic University, Pomona: 64 p.

Stuiver, M. 1969 Yale natural radiocarbon measurements IX. Radiocarbon 11(2): 545-658.

Wells, S. G., Anderson, R. Y., McFadden, L. D., Brown, W. J., Enzel, Y. and Miossec, J. L. 1989 Late Quaternary Paleohydrology of the Eastern Mojave River Drainage, Southern California: Quantitative Assessment of the Late Quaternary Hydrologic Cycle in Large Arid Watersheds. Report 242, New Mexico Water Resources Research Institute, Las Cruces: $253 \mathrm{p}$. 